\title{
PERAN SELF-EFFICACY DAN SELF-CONTROL TERHADAP PROKRASTINASI AKADEMIK PADA SISWA SMA (STUDI PADA SISWA SMA $X$ TANGERANG)
}

\author{
Cindy Clara', Agoes Dariyo², Debora Basaria ${ }^{3}$ \\ ${ }^{1}$ Fakultas Psikologi Universitas Tarumanagara \\ E-mail: cindyclr0795@gmail.com \\ ${ }^{2}$ Fakultas Psikologi Universitas Tarumanagara \\ E-mail: agoesd@fpsi.untar.ac.id \\ ${ }^{3}$ Fakultas Psikologi Universitas Tarumanagara
}

\begin{abstract}
ABSTRAK
Prokrastinasi akademik merujuk pada penundaan yang hanya terbatas pada tugas dan aktivitas yang berkaitan dengan pembelajaran. Prokrastinasi akademik dianggap sebagai permasalahan yang umum terjadi pada para pelajar. Tujuan penelitian ini adalah untuk mengetahui peran self-efficacy dan self-control terhadap prokrastinasi akademik pada siswa SMA. Penelitian ini merupakan penelitian kuantitatif non eksperimen yang menyertakan 395 siswa SMA X Tangerang dengan menggunakan teknik sampling jenuh. Instrumen yang digunakan untuk mengukur variabel adalah skala Self-Efficacy oleh Jovita yang disusun berdasarkan teori Bandura; Self-Control Scale oleh Tangney, Baumeister, dan Boone; dan skala prokrastinasi akademik yang disusun berdasarkan teori Schouwenburg. Analisis data dilakukan dengan menggunakan teknik regresi linier berganda melalui program SPSS versi 18. Hasil penelitian menunjukkan bahwa self-efficacy dan self-control memiliki peran yang signifikan secara simultan terhadap prokrastinasi akademik $(F=138.373, p=0.000<0.05)$. Self-efficacy dan self-control secara simultan berkontribusi terhadap prokrastinasi akademik sebesar 41.4\%, sedangkan 58.6\% prokrastinasi akademik dipengaruhi oleh variabel lain yang tidak diteliti dalam penelitian ini. Selain itu, hasil penelitian menunjukkan bahwa self-control lebih berperan terhadap prokrastinasi akademik dibandingkan dengan self-efficacy.
\end{abstract}

Kata kunci: prokrastinasi akademik, self-efficacy, self-control, siswa SMA

\section{PENDAHULUAN}

Prokrastinasi merupakan sebuah istilah yang merujuk pada penundaan yang dilakukan dengan sengaja oleh individu terhadap tugas atau pekerjaannya dan individu tersebut mengetahui bahwa penundaannya dapat berdampak buruk (Steel, 2007). Dalam bidang pendidikan, terdapat pula istilah prokrastinasi akademik. Prokrastinasi akademik adalah penundaan yang hanya terbatas pada tugas dan aktivitas yang berkaitan dengan pembelajaran (Steel \& Klingsieck, 2016). Beberapa hasil penelitian menunjukkan bahwa prokrastinasi akademik memiliki dampak negatif bagi individu. Dampak-dampak negatif tersebut, di antaranya distress, rendahnya prestasi akademik, tugas tidak terselesaikan atau hasil pengerjaan tugas tidak maksimal, serta menurunkan produktivitas sehingga waktu yang dimiliki menjadi terbuang sia-sia (Solomon \& Rothblum, 1984; Tice \& Baumeister, 1997; Karatas, 2015).

Prokrastinasi akademik dianggap sebagai permasalahan yang umum terjadi pada para pelajar (Day, Mensink, \& O'Sullivan; Schouwenburg; Solomon \& Rothblum; Wolters; dikutip dalam Chow, 2011). Dalam penelitian Janssen (2015), 57.1\% dari 133 mahasiswa berada pada kategori prokrastinasi akademik yang tinggi. Sementara itu, hasil penelitian Solomon dan Rothblum (1984) pada 342 mahasiswa menunjukkan bahwa mahasiswa yang melakukan prokrastinasi pada tugas menulis sebanyak $46 \%$, belajar untuk ujian sebanyak $27.6 \%$, dan tugas membaca sebanyak $30.1 \%$.

Selama ini, penelitian mengenai prokrastinasi akademik lebih sering berfokus pada mahasiswa dan hanya sedikit diteliti pada siswa (Klassen et al., dikutip dalam Katz, Eilo, \& Nevo, 2014). 
Padahal, hasil survei yang dilakukan oleh StudyMode pada tahun 2014 menunjukkan bahwa sebanyak 86\% dari 611 siswa Sekolah Menengah Atas (SMA) melakukan prokrastinasi terhadap tugas-tugas akademik mereka (dikutip dalam Klein, 2014; PR Newswire, 2014). Lebih lanjut, berdasarkan penelitian Janssen (2015) pada 98 siswa SMA di Amerika Serikat, diperoleh hasil sebagai berikut (a) 5\% siswa berada pada kategori prokrastinasi akademik yang rendah, (b) $34.7 \%$ siswa berada pada kategori prokrastinasi akademik menengah, (c) 49\% siswa berada pada kategori prokrastinasi akademik yang tinggi, dan (d) $11.2 \%$ siswa berada pada kategori prokrastinasi akademik yang sangat tinggi.

Beberapa penelitian mengenai prokrastinasi akademik pada siswa SMA juga dilakukan di Indonesia. Pertama, berdasarkan hasil penelitian Savira dan Suharsono (2013) pada 48 siswa kelas XI program akselerasi di SMA Negeri Kota Malang, diketahui bahwa 52.1\% siswa berada pada kategori prokrastinasi akademik yang tinggi. Kedua, hasil penelitian Sari (2013) pada 120 siswa kelas XII di SMA Muhammadiyah 2 Yogyakarta menunjukkan bahwa 66.7\% siswa berada pada kategori prokrastinasi akademik sedang. Ketiga, Ulum (2016) menemukan bahwa 79.4\% dari 68 siswa kelas XI IPA di SMA Negeri 1 Ngamprah Kabupaten Bandung Barat berada pada kategori prokrastinasi akademik sedang.

Menurut Schouwenburg (1995), prokrastinasi akademik terdiri dari empat komponen, yaitu (a) menunda untuk memulai atau menyelesaikan tugas, (b) keterlambatan dalam menyelesaikan tugas, (c) kesenjangan waktu antara rencana dengan realisasi pengerjaan tugas, dan (d) memilih untuk melakukan aktivitas lain yang dianggap lebih menyenangkan. Peneliti menemukan fenomena prokrastinasi akademik pada siswa SMA yang sesuai dengan komponen yang dikemukakan oleh Schouwenburg melalui komunikasi personal dengan dua orang siswa SMA. Siswa SMA pertama berinisial F. F merupakan salah satu siswa SMA kelas XI IPA berjenis kelamin perempuan. F mengaku bahwa ia sering melakukan prokrastinasi dalam pengerjaan tugas serta belajar. Berkaitan dengan pengerjaan tugas, F pernah sesekali mengerjakan seluruh tugas dalam waktu satu malam sebelum tugas-tugas tersebut dikumpulkan di hari selanjutnya dan sesekali mengerjakan tugas di sekolah pada pagi hari sebelum kelas dimulai. Selain itu, ia juga pernah terlambat mengumpulkan tugas sehingga nilai tugas dikurangi oleh guru (komunikasi personal, 2 November 2016).

F mengemukakan beberapa alasan ia melakukan prokrastinasi, di antaranya merasa tidak mampu mengerjakan tugas karena guru tidak menjelaskan materi tugas dan tidak menyukai mata pelajaran tertentu. Kedua hal tersebut menyebabkan $\mathrm{F}$ merasa malas sehingga ia pun melakukan prokrastinasi. F sering membuat target waktu untuk pengerjaan tugas dan belajar, namun waktu pelaksanaannya seringkali melewati target yang direncanakan sebelumnya. Hal ini dikarenakan ia lebih memilih untuk melakukan aktivitas lain yang dianggapnya lebih menyenangkan, yaitu bermain handphone, mendengarkan musik, dan menonton TV. F mengaku bahwa perilaku prokrastinasi tersebut memberikan efek negatif bagi dirinya, seperti merasa terburu-buru, hasil pengerjaan tugas menjadi kurang maksimal, dan nilai tugasnya dikurangi oleh guru karena terlambat mengumpulkan tugas (komunikasi personal, 2 November 2016).

Selain F, terdapat pula seorang siswa laki-laki berinisial A yang berasal dari kelas XI IPS. A mengaku bahwa ia sangat sering melakukan prokrastinasi dalam hal mengerjakan tugas dan belajar. A melakukan prokrastinasi karena ia menganggap aktivitas bersosialisasi melalui bermain game atau bermain bersama teman lebih menyenangkan daripada mengerjakan tugas 
maupun belajar. Selain itu, ia kerap menyepelekan tugas-tugasnya karena merasa dapat menyontek pada pagi hari di sekolah sehingga menjadi malas dan memutuskan untuk melakukan prokrastinasi dalam pengerjaan tugas (komunikasi personal, 2 November 2016).

A mengaku bahwa dirinya kurang disiplin sehingga mudah tergoda untuk melakukan aktivitasaktivitas yang ia anggap memang tidak relevan dengan bidang pendidikan, seperti menonton, bermain game, dan bermain bersama teman. Dengan demikian, waktu yang seharusnya digunakan untuk mengerjakan tugas maupun belajar menjadi tersita untuk melakukan aktivitasaktivitas tersebut. Menurut A, dampak negatif bagi dirinya akibat prokrastinasi, yaitu hasil pengerjaan tugas dan nilai yang diperoleh menjadi tidak maksimal karena terburu-buru ketika mengerjakan tugas. Dampak negatif lainnya adalah A menjadi merasa tidak tenang di sekolah karena mengetahui telah melakukan kesalahan dengan tidak mengerjakan tugas (komunikasi personal, 2 November 2016).

Tingginya perilaku prokrastinasi akademik seringkali berkaitan dengan rendahnya faktor-faktor internal individu. Faktor-faktor internal tersebut, di antaranya self-efficacy (AlQudah, Alsubhien, \& Heilat, 2014; Roghani, Aghahoseini, \& Yazdani, 2015; Lowinger et al., 2016) dan self-control (Steel, 2007). Self-efficacy merupakan keyakinan individu terhadap kemampuannya dalam mengatur dan melakukan tindakan untuk mencapai hasil tertentu (Bandura, 1997). Schunk (dikutip dalam Santrock, 2011) berpendapat bahwa self-efficacy mempengaruhi pilihan para pelajar dalam beraktivitas. Pelajar dengan self-efficacy yang rendah cenderung memilih untuk menghindari tugas yang banyak, terutama tugas yang sulit (Schunk \& Pajares, dikutip dalam Santrock, 2011). Perilaku menghindari tugas tersebut merupakan karakteristik dari prokrastinasi akademik (Gargari, Sabouri, \& Norzad, 2011). Sementara itu, pelajar dengan self-efficacy yang tinggi akan bersemangat dalam menghadapi tugas tersebut. Pelajar dengan self-efficacy yang tinggi juga akan lebih gigih dalam berusaha untuk mengerjakan tugas daripada pelajar dengan self-efficacy yang rendah (Schunk \& Pajares, dikutip dalam Santrock, 2011).

Beberapa hasil penelitian menunjukkan bahwa terdapat korelasi negatif yang signifikan antara self-efficacy dengan prokrastinasi akademik (AlQudah et al., 2014; Roghani et al., 2015; Lowinger et al., 2016). Hal ini berarti semakin tinggi self-efficacy yang dimiliki oleh seorang pelajar, maka semakin rendah kecenderungan perilaku prokrastinasi akademik pelajar tersebut. Sebaliknya, semakin rendah self-efficacy yang dimiliki oleh seorang pelajar, maka perilaku prokrastinasi akademik pada pelajar tersebut cenderung semakin tinggi.

Sementara itu, self-control merupakan kemampuan individu untuk mengesampingkan atau mengubah reaksi batin, baik menghentikan perilaku yang tidak diinginkan maupun menahan diri untuk tidak bertindak demikian (Tangney, Baumeister, \& Boone, 2004). Tangney et al. (2004) menyatakan bahwa self-control menghasilkan berbagai hal positif dalam kehidupan individu, salah satunya dalam bidang pendidikan. Pelajar dengan self-control yang tinggi dikatakan memiliki prestasi akademik yang lebih baik daripada pelajar dengan self-control yang rendah.

Berkaitan dengan prokrastinasi akademik, Tice dan Baumeister (dikutip dalam Tangney et al., 2004) menemukan bahwa pelajar dengan self-control yang buruk cenderung melakukan prokrastinasi sehingga menghasilkan prestasi akademik yang buruk. Steel (2007) juga mengemukakan bahwa individu yang melakukan prokrastinasi cenderung impulsif, mudah teralihkan, dan kurang memiliki self-control. Selain itu, berdasarkan hasil penelitian Susanti dan Nurwidawati (2014), diketahui bahwa terdapat korelasi yang signifikan antara self-control dan prokrastinasi akademik pada mahasiswa Program Studi Psikologi Unesa. Lebih lanjut, Susanti dan Nurwidawati (2014) mengemukakan bahwa self-control memiliki kontribusi sebesar 48.5\% 
terhadap terjadinya prokrastinasi akademik di kalangan mahasiswa Program Studi Psikologi Unesa.

Berdasarkan fenomena yang telah disebutkan sebelumnya, peneliti melihat bahwa penyebab prokrastinasi akademik pada siswa SMA berkaitan dengan variabel self-efficacy dan self-control. Penyebab yang dimaksud adalah merasa tidak mampu mengerjakan tugas, malas, dan kurang disiplin sehingga menyepelekan tugas serta mudah tergoda untuk melakukan aktivitas yang tidak berkaitan dengan aktivitas akademik. Peneliti pun tertarik untuk melakukan penelitian mengenai peran self-efficacy dan self-control terhadap prokrastinasi akademik siswa SMA. Peneliti menggunakan variabel self-efficacy dan self-control sebagai variabel prediktor karena peneliti juga ingin melihat variabel prediktor mana yang memiliki kontribusi yang lebih besar terhadap prokrastinasi akademik pada siswa SMA.

\section{METODE PENELITIAN}

\section{Subyek Penelitian}

Karakteristik subyek dalam penelitian ini adalah (a) siswa kelas X dan XI di SMA X Tangerang, (b) berjenis kelamin laki-laki dan perempuan, dan (c) berusia 14-18 tahun. Populasi siswa kelas $\mathrm{X}$ dan XI di SMA X Tangerang adalah sebanyak 506 siswa. Teknik pengambilan sampel yang digunakan adalah nonprobability sampling berupa sampling jenuh. Jumlah subyek yang diperoleh adalah sebanyak 429 siswa, namun jumlah tersebut berkurang menjadi 395 setelah peneliti melakukan screening.

\section{Jenis Penelitian}

Penelitian ini merupakan penelitian kuantitatif non eksperimen untuk menguji peran dua variabel independen terhadap satu variabel dependen melalui uji regresi linier berganda.

\section{Pengukuran Variabel Self-efficacy}

Variabel self-efficacy diukur menggunakan skala Self-Efficacy yang dirancang oleh Jovita (2015). Jenis skala yang digunakan adalah skala Likert dengan lima pilihan jawaban, yaitu Tidak Pernah (TP), Jarang (JR), Kadang-kadang (KK), Sering (SR), dan Selalu (SLL). Pada butir positif, jawaban TP memperoleh skor 1, JR memperoleh skor 2, KK memperoleh skor 3, SR memperoleh skor 4, dan SLL memperoleh skor 5. Sebaliknya, pada butir negatif, jawaban TP memperoleh skor 5, JR memperoleh skor 4, KK memperoleh skor 3, SR memperoleh skor 2, dan SLL memperoleh skor 1 . Skala ini memiliki total pernyataan sebanyak 18 butir yang terdiri dari sembilan butir positif dan sembilan butir negatif serta mengacu pada tiga dimensi self-efficacy berupa level, generality, dan strength yang dikemukakan oleh Bandura (1997). Hasil uji reliabilitas skala Self-Efficacy yang dilakukan oleh peneliti pada 65 subyek dapat dilihat pada Tabel 1 
Tabel 1. Uji Reliabilitas Skala Self-Efficacy

\begin{tabular}{lcccc}
\hline & \multicolumn{2}{c}{ Jumlah Butir } & \multicolumn{2}{c}{$\alpha$ Cronbach } \\
\cline { 2 - 5 } \multicolumn{1}{c}{ Dimensi } & $\begin{array}{c}\text { Sebelum Uji } \\
\text { Reliabilitas }\end{array}$ & $\begin{array}{c}\text { Sesudah Uji } \\
\text { Reliabilitas }\end{array}$ & $\begin{array}{c}\text { Sebelum Uji } \\
\text { Reliabilitas }\end{array}$ & $\begin{array}{c}\text { Sesudah Uji } \\
\text { Reliabilitas }\end{array}$ \\
\hline Level & 6 & 6 & 0.553 & 0.553 \\
Generality & 6 & 6 & 0.684 & 0.684 \\
Strength & 6 & 6 & 0.688 & 0.688 \\
\hline
\end{tabular}

\section{Pengukuran Variabel Self-control}

Variabel self-control diukur menggunakan kuesioner berjudul Self-Control Scale yang dirancang oleh Tangney et al. (2004). Peneliti mengadaptasi skala ini dengan cara melakukan penerjemahan dari Bahasa Inggris menjadi Bahasa Indonesia melalui penerjemah tersumpah. Jenis skala yang digunakan pada Self-Control Scale adalah skala Likert dengan lima interval jawaban dari angka 1 yang berarti sangat tidak sesuai hingga 5 yang berarti sangat sesuai. Untuk memudahkan subyek dalam menentukan pilihan jawaban, peneliti memberikan keterangan pilihan jawaban Sangat Tidak Sesuai (STS), Tidak Sesuai (TS), Ragu-Ragu (RR), Sesuai (S), dan Sangat Sesuai (SS). Dalam proses scoring butir-butir pernyataan positif, jawaban STS memperoleh skor 1, TS memperoleh skor 2, RR memperoleh skor 3, S memperoleh skor 4, dan SS memperoleh skor 5. Sebaliknya, pada butir-butir pernyataan negatif, jawaban STS memperoleh skor 5, TS memperoleh skor 4, RR memperoleh skor 3, S memperoleh skor 2, dan SS memperoleh skor 1. Semakin tinggi total skor subyek, maka semakin tinggi self-control yang dimiliki oleh subyek.

Self-Control Scale memiliki 36 butir pernyataan yang terdiri dari 12 butir positif dan 24 butir negatif. Berdasarkan hasil analisis faktor, Tangney et al. (2004) mengemukakan bahwa 36 butir tersebut mengandung lima dimensi, yaitu self-discipline, deliberate/non-impulsive action, healthy habits, work ethic, dan reliability. Hasil uji reliabilitas Self-Control Scale yang dilakukan oleh peneliti pada 65 subyek dapat dilihat pada Tabel 2 . 
Tabel 2. Uji Reliabilitas Self-Control Scale

\begin{tabular}{lcccc}
\hline & \multicolumn{2}{c}{ Jumlah Butir } & \multicolumn{2}{c}{$\alpha$ Cronbach } \\
\cline { 2 - 5 } \multicolumn{1}{c}{ Dimensi } & $\begin{array}{c}\text { Sebelum Uji } \\
\text { Reliabilitas }\end{array}$ & $\begin{array}{c}\text { Sesudah Uji } \\
\text { Reliabilitas }\end{array}$ & $\begin{array}{c}\text { Sebelum Uji } \\
\text { Reliabilitas }\end{array}$ & $\begin{array}{c}\text { Sesudah Uji } \\
\text { Reliabilitas }\end{array}$ \\
\hline $\begin{array}{l}\text { Self-discipline } \\
\begin{array}{l}\text { Deliberate/nonimpulsive } \\
\text { action }\end{array}\end{array}$ & 11 & 6 & 0.449 & 0.667 \\
$\begin{array}{l}\text { Healthy habits } \\
\text { Work ethic }\end{array}$ & 5 & 8 & 0.690 & 0.725 \\
Reliability & 5 & 5 & 0.645 & 0.645 \\
\hline
\end{tabular}

\section{Pengukuran Variabel Prokrastinasi Akademik}

Variabel prokrastinasi akademik diukur menggunakan skala prokrastinasi akademik yang dirancang sendiri oleh peneliti sesuai dengan empat komponen prokrastinasi akademik yang dikemukakan oleh Schouwenburg (1995), yaitu (a) menunda untuk memulai atau menyelesaikan tugas, (b) keterlambatan dalam menyelesaikan tugas, (c) kesenjangan waktu antara rencana dengan realisasi pengerjaan tugas, dan (d) memilih untuk melakukan aktivitas lain yang dianggap lebih menyenangkan.

Skala prokrastinasi akademik ini memiliki 16 butir yang terdiri dari 8 butir positif dan 8 butir negatif. Jenis skala yang digunakan adalah skala Likert dengan lima pilihan jawaban yang terdiri dari Tidak Pernah (TP), Jarang (JR), Kadang-kadang (KK), Sering (SR), dan Selalu (SLL). Pada butir positif, jawaban TP memperoleh skor 1, JR memperoleh skor 2, KK memperoleh skor 3, SR memperoleh skor 4, dan SLL memperoleh skor 5. Sebaliknya, pada butir negatif, jawaban TP memperoleh skor 5, JR memperoleh skor 4, KK memperoleh skor 3, SR memperoleh skor 2, dan SLL memperoleh skor 1. Semakin tinggi total skor subyek, maka semakin tinggi prokrastinasi akademik subyek. Hasil uji reliabilitas skala prokrastinasi akademik yang dilakukan oleh peneliti pada 65 subyek dapat dilihat pada Tabel 3 . 
Tabel 3. Uji Reliabilitas Skala Prokrastinasi Akademik

\begin{tabular}{ccccc}
\hline & \multicolumn{2}{c}{ Jumlah Butir } & \multicolumn{2}{c}{$\alpha$ Cronbach } \\
\cline { 2 - 5 } Komponen & $\begin{array}{c}\text { Sebelum Uji } \\
\text { Reliabilitas }\end{array}$ & $\begin{array}{c}\text { Sesudah Uji } \\
\text { Reliabilitas }\end{array}$ & $\begin{array}{c}\text { Sebelum Uji } \\
\text { Reliabilitas }\end{array}$ & $\begin{array}{c}\text { Sesudah Uji } \\
\text { Reliabilitas }\end{array}$ \\
\hline I & 4 & 4 & 0.813 & 0.813 \\
II & 4 & 4 & 0.749 & 0.749 \\
III & 4 & 4 & 0.752 & 0.752 \\
IV & 4 & 4 & 0.776 & 0.776 \\
\hline
\end{tabular}

\section{HASIL DAN PEMBAHASAN}

Berdasarkan hasil uji regresi linier berganda, diperoleh nilai $F=138.373, p=0.000<0.05$ yang berarti bahwa self-efficacy dan self-control secara simultan memiliki peran yang signifikan terhadap prokrastinasi akademik. Dengan demikian, hipotesis penelitian ini diterima bahwa selfefficacy dan self-control memiliki peran terhadap prokrastinasi akademik pada siswa SMA. Selain itu, dari hasil uji regresi linier berganda diperoleh nilai $R^{2}=0.414$ yang menjelaskan bahwa besar kontribusi self-efficacy dan self-control secara simultan terhadap prokrastinasi akademik adalah sebesar $41.4 \%$, sedangkan 58.6\% dipengaruhi oleh variabel lain yang tidak diteliti dalam penelitian ini.

Selanjutnya, peran self-efficacy dan self-control terhadap prokrastinasi akademik secara parsial dapat dilihat melalui nilai $t$ dan $p$. Nilai $t$ variabel self-efficacy sebesar -6.497 dengan $p$ sebesar $0.000(p<0.05)$ yang berarti bahwa self-efficacy memiliki peran yang signifikan terhadap prokrastinasi akademik. Nilai $t$ negatif menunjukkan peran yang tidak searah sehingga semakin tinggi self-efficacy subyek, maka prokrastinasi akademik subyek akan semakin rendah, dan juga berlaku sebaliknya.

Sementara itu, nilai t variabel self-control adalah sebesar -10.295 dengan $p$ sebesar $0.000(p<$ 0.05). Hal ini berarti bahwa self-control memiliki peran yang signifikan terhadap prokrastinasi akademik. Nilai $t$ negatif menunjukkan peran yang tidak searah sehingga semakin tinggi selfcontrol subyek, maka prokrastinasi akademik subyek akan semakin rendah, dan juga berlaku sebaliknya. Berdasarkan masing-masing nilai t variabel yang diperoleh dari tabel Coefficients, diketahui bahwa self-control $(t=-10.295, p=0.000<0.05)$ lebih berperan terhadap prokrastinasi akademik dibandingkan dengan self-efficacy $(t=-6.497, p=0.000<0.05)$. Ringkasan uji peran self-efficacy dan self-control terhadap prokrastinasi akademik dapat dilihat pada Tabel 4. 
PERAN SELF-EFFICACY DAN SELF-CONTROL TERHADAP PROKRASTINASI AKADEMIK PADA

Tabel 4. Peran Self-efficacy dan Self-control terhadap Prokrastinasi Akademik

\begin{tabular}{cccccc}
\hline$R^{2}$ & $F$ & $p$ & Variabel & $t$ & $p$ \\
\hline 0.414 & 138.373 & 0.000 & Self-efficacy & -6.497 & 0.000 \\
& & & Self-control & -10.295 & 0.000 \\
\hline
\end{tabular}

Berdasarkan hasil analisis data utama, diketahui bahwa self-efficacy dan self-control memiliki peran yang signifikan secara simultan terhadap prokrastinasi akademik pada siswa SMA dengan kontribusi sebesar $41.4 \%$. Hal ini berarti bahwa 58.6\% prokrastinasi akademik dapat dijelaskan dengan variabel self-efficacy dan self-control.

Self-efficacy merupakan keyakinan individu terhadap kemampuannya dalam bertindak, menyelesaikan sesuatu, atau mencapai hasil dalam kondisi tertentu. Self-efficacy hanya melibatkan proses kognitif pada individu. Sementara itu, self-control merupakan sebagai kemampuan individu untuk mengesampingkan atau mengubah pemikiran, emosi, dorongan, godaan, dan perilaku yang tidak diinginkan sehingga dapat membawa ke arah konsekuensi positif. Lebih lanjut, Averill (1973) menyatakan bahwa self-control meliputi tiga aspek, yaitu mengontrol kognitif, mengontrol perilaku, dan mengontrol keputusan.

Individu yang meyakini bahwa dirinya mampu untuk bertindak, menyelesaikan sesuatu, atau mencapai suatu hasil belum tentu mampu menahan atau mengesampingkan dorongan, godaan, atau perilaku yang negatif. Dorongan, godaan, atau perilaku negatif yang dimaksud dalam penelitian ini adalah prokrastinasi akademik. Oleh karena itu, self-efficacy harus disertai juga dengan self-control sehingga memiliki peran terhadap prokrastinasi akademik. Hal ini dapat menjelaskan mengapa self-efficacy dan self-control secara simultan memiliki peran yang signifikan terhadap prokrastinasi akademik pada siswa SMA dengan kontribusi sebesar $41.4 \%$. Hal ini juga dapat menjelaskan hasil analisis data utama lainnya, yaitu self-control lebih berperan terhadap prokrastinasi akademik dibandingkan dengan self-efficacy.

Hasil analisis data menunjukkan bahwa self-efficacy secara parsial memiliki peran negatif yang signifikan terhadap prokrastinasi akademik pada siswa SMA. Hasil penelitian ini mendukung penelitian AlQudah et al. (2014) dan Roghani et al. (2015) yang menyatakan bahwa terdapat korelasi negatif antara self-efficacy dan prokrastinasi akademik. Subyek penelitian AlQudah et al. (2014) adalah 195 mahasiswa Universitas Raja Saud, Arab Saudi, sedangkan subyek penelitian Roghani et al. (2015) adalah 116 siswa SMA berjenis kelamin perempuan di Ishafan, Iran. Selain itu, hasil penelitian ini sejalan dengan pernyataan Lowinger et al. (2016) bahwa selfefficacy menjadi prediktor prokrastinasi akademik pada mahasiswa Asia non India yang berkuliah di enam universitas di Amerika Serikat.

Hasil analisis data berikutnya adalah self-control secara parsial juga memiliki peran negatif yang signifikan terhadap prokrastinasi akademik pada siswa SMA. Hasil penelitian ini mendukung pernyataan Steel (2007) bahwa individu yang melakukan prokrastinasi umumnya kurang memiliki self-control. Selain itu, hasil penelitian ini sesuai dengan penelitian Susanti dan Nurwidawati (2014) yang menemukan bahwa terdapat korelasi yang signifikan antara self- 
control dan prokrastinasi akademik pada mahasiswa Program Studi Psikologi Unesa. Lebih lanjut, Susanti dan Nurwidawati (2014) mengemukakan bahwa self-control memiliki kontribusi sebesar $48.5 \%$ terhadap terjadinya prokrastinasi akademik di kalangan mahasiswa Program Studi Psikologi Unesa.

Penelitian ini memiliki beberapa keterbatasan. Pertama, peneliti hanya menggunakan variabel self-efficacy dan self-control sebagai variabel prediktor prokrastinasi akademik dalam penelitian ini, sedangkan masih terdapat variabel-variabel lain seperti self-regulation, ketakutan akan kegagalan, perfeksionisme, motivasi belajar, motivasi berprestasi, dan lain-lain yang mungkin dapat menjadi variabel prediktor prokrastinasi akademik. Kedua, subyek penelitian yang digunakan hanya siswa yang berasal dari SMA X Tangerang. Hal ini menyebabkan hasil penelitian tidak dapat digeneralisasi untuk para siswa di SMA lainnya. Ketiga, keterbatasan penelitian terletak pada reliabilitas konsistensi internal tiga dimensi skala Self-Efficacy dan empat dimensi Self-Control Scale yang tidak optimal karena memiliki nilai Alpha Cronbach yang kurang dari 0.700 .

\section{KESIMPULAN DAN SARAN}

Berdasarkan hasil analisis data yang telah dilakukan, maka dapat disimpulkan bahwa selfefficacy dan self-control memiliki peran yang signifikan secara simultan terhadap prokrastinasi akademik pada siswa SMA. Hasil analisis data juga menunjukkan bahwa self-control lebih berperan terhadap prokrastinasi akademik dibandingkan dengan self-efficacy.

\section{REFERENSI}

AlQudah, M. F., Alsubhien, A. M., \& Heilat, M. Q. A. (2014). The relationship between the academic procrastination and self-efficacy among sample of King Saud University students. Journal of Education and Practice, 5(16), 101-111. Retrieved from http://www.iiste.org/Journals/index.php/JEP/article/view/13076/13647

Averill, J. R. (1973). Personal control over aversive stimuli and its relationship to stress. Psychological Bulletin, 80(4), 286-303. Retrieved from http://psycnet.apa.org/journals/bul/80/4/286.pdf

Bandura, A. (1997). Self efficacy: The exercise of control. New York, NY: W. H. Freeman and Company.

Chow, H. P. H. (2011). Procrastination among undergraduate students: Effects of emotional intelligence, school life, self-evaluation, and self-efficacy. Alberta Journal of Educational Research, 57(2), 234-240. Retrieved from http://ajer.journalhosting.ucalgary.ca/index.php/ajer/article/viewFile/894/828

Gargari, R. B., Sabouri, H., \& Norzad, F. (2011). Academic procrastination: The relationship between causal attribution styles and behavioral postponement. Iranian Journal of Psychiatry and Behavioral Sciences, 5(2). Retrieved from http://www.ncbi.nlm.nih.gov/pmc/articles/PMC3939975/

Janssen, J. O. (2015). Academic procrastination: prevalence among high school and undergraduate student and relationship to academic achievement (Doctoral dissertation). Retrieved from http://scholarworks.gsu.edu/epse_diss/103

Jovita. (2015). Perbedaan self-efficacy ditinjau dari pola asuh orangtua (studi pada pelajar SMA $X$ dan $Y$ di Jakarta Utara). (Skripsi tidak diterbitkan). Universitas Tarumanagara, Jakarta Barat, DKI Jakarta. 
PERAN SELF-EFFICACY DAN SELF-CONTROL TERHADAP PROKRASTINASI AKADEMIK PADA

Karatas, H. (2015). Correlation among academic procrastination, personality traits, and academic achievement. Anthropologist, 20(1,2), 243-255. Retrieved from http://krepublishers.com/02-Journals/T-Anth/Anth-20-0-000-15-Web/Anth-20-1-000-15Abst-PDF/T-ANTH-20-1,2-243-15-1439-Karatas-H/T-ANTH-20-1,2-243-15-1439Karatas-H-Tx[27].pdf

Katz, I., Eilot, K., \& Nevo, N. (2014). "I'll do it later": Type of motivation, self efficacy, and homework procrastination. Motiv Emot, 38, 111-119. doi: 10.1007/s11031-013-9366-1

Klein, R. (2014, May 27). Here's what procrastinators are doing instead of schoolwork. The Huffington Post. Retrieved from http://www.huffingtonpost.com/2014/05/27/studentprocrastinating-statistics_n_5399284.html

Lowinger, R. J., Kuo, B. C. H., Song, H., Mahadevan, L., Kim, E., Liao, K. Y. H., ... Han, S. (2016). Predictors of academic procrastination in Asian international college students. Journal of Student Affairs Research and Practice, 53(1), 90-104. Retrieved from http://www1.uwindsor.ca/people/benkuo/system/files/PredictorsofAcademicProcrastinati oninAsianInternationalStudents.pdf

PR Newswire. (2014, May 27). Eighty-seven percent of high school and college students are self-proclaimed procrastinators. $P R \quad$ Newswire. Retrieved from http://www.prnewswire.com/news-releases/eighty-seven-percent-of-high-school-andcollege-students-are-self-proclaimed-procrastinators-260750441.html

Roghani, L., Aghahoseini, T., \& Yazdani, F. (2015). The relationship between the academic procrastination and the academic self-efficacy for academic achievements in female high school students in Isfahan in the 2013-2014 academic year. Journal of Management Sciences, 1(12), 385-390. Retrieved from http://www.jmsjournal.com/fulltext/paper29102015155447.pdf

Santrock, J. W. (2011). Educational psychology (5th ed.). New York, NY: McGraw-Hill.

Sari, D. N. (2013). Hubungan antara stres terhadap guru dengan prokrastinasi akademik pada siswa SMA Muhammadiyah 2 Yogyakarta. EMPATHY: Jurnal Fakultas Psikologi, 2(1). Diunduh dari http://www.jogjapress.com/index.php/EMPATHY/article/view/1525/863

Savira, F., \& Suharsono, Y. (2013). Self-regulated learning (SRL) dengan prokrastinasi akademik pada siswa akselerasi. Jurnal Ilmiah Psikologi Terapan, 1(1), 66-75.

Schouwenburg, H. C. (1995). Academic procrastination: Theoretical notions, measurement, and research. In J. R. Ferrari, J. L. Johnson, \& W. G. McCown (Ed.), Procrastination and task avoidance: Theory, research, and treatment. New York, NY: Springer Science+Business Media.

Solomon, L. J., \& Rothblum, E. D. (1984). Academic procrastination: Frequency and cognitivebehavior correlates. Journal of Counseling Psychology, 31(4), 503-509. Retrieved from http://rothblum.sdsu.edu/doc_pdf/procrastination/AcademicProcrastinationFrequency.pdf

Steel, P. (2007). The nature of procrastination. Psychological Bulletin, 133(1), 65-94. Retrieved from http://studiemetro.au.dk/fileadmin/www.studiemetro.au.dk/Procrastination_2.pdf

Steel, P., \& Klingsieck, K. B. (2016). Academic procrastination: Psychological antecedents revisited. Australian Psychologist, 51, 36-46. doi:10.1111/ap.12173

Susanti, E., \& Nurwidawati, D. (2014). Hubungan antara kontrol diri dan konformitas dengan prokrastinasi akademik pada mahasiswa program studi psikologi Unesa. Character, 2(3), 1-7. Diunduh dari jurnalmahasiswa.unesa.ac.id/article/14341/17/article.pdf

Tangney, J. P., Baumeister, R. F., \& Boone, A. L. (2004). High self-control predicts good adjustment, less pathology, better grades, and interpersonal success. Journal of 
Personality, $72(2)$

271-322.

Retrieved

from

http://onlinelibrary.wiley.com/doi/10.1111/j.0022-3506.2004.00263.x/abstract

Tice, D. M., \& Baumeister, R. F. (1997). Longitudinal study of procrastination, performance, stress, and health: The costs and benefits of dawdling. Psychological Science, 8(6), 454458.

Retrieved

from https://www.amherst.edu/media/view/230062/original/procrastinating.pdf

Ulum, M. I. (2016). Strategi self-regulated learning untuk menurunkan tingkat prokrastinasi akademik siswa. Psympathic: Jurnal Ilmiah Psikologi, 3(2), 153-170. http://dx.doi.org/10.15575/psy.v3 